\title{
O MERCOSUL E 0 ETERNO RETORNO
}

Com a assinatura do Tratado de Assunção, que instituiu o Mercosul em 26 de março de 1991, anunciava-se uma era de grande prosperidade econômica para os quatro países signatários que, apesar de vizinhos, até então eram mais rivais do que parceiros econômicos. Apesar do clima otimista devido à então recente transição dos regimes autoritários da região para a democracia, um obstáculo considerável a ser enfrentado parecia ser a rivalidade histórica entre brasileiros e argentinos. Um comentário do senador Pedro Simon (PMDB/RS) naquele mesmo ano revelava o grande caminho a ser percorrido para a desejada integração regional:

"Os dois países se davam tão mal no passado que nós fizemos no Rio Grande do Sul uma estrada de ferro com bitola estreita, diferente da bitola larga da Argentina, só para dificultar uma possível invasão do Brasil pelos argentinos. Havia coisas dessa natureza.” (Westin, 2021)

Passadas três décadas daquele acordo histórico, que projetava tantos sonhos para o futuro, o balanço não é muito animador e um promissor acordo de livre mercado entre o Mercosul e a União Europeia (UE) pena em sair do papel devido a divergências sobre a questão ambiental e a má vontade do atual governo federal em combater o desmatamento na Amazônia. "É preciso pôr fim ao acordo de livre comércio com o Mercosul, que é a encarnação de uma globalização do desmatamento, dos alimentos pobres em nutrientes, do sofrimento dos animais, do desaparecimento dos camponeses e da dependência alimentar", afirmou recentemente Yannick Jadot, deputado dos partidos verdes no parlamento europeu, na esteira do desentendimento entre os presidentes do Brasil e da França sobre as prioridades ambientais e a consequente inviabilização do acordo entre o Mercosul e a União Europeia (Le Monde, 2021, p. 31). 
Os artigos publicados na imprensa por ocasião do aniversário de trinta anos do Mercosul são bastante pessimistas para o futuro do bloco. Para Andres Malamud, um estudioso da integração regional na América Latina, "o Mercosul se afunda na irrelevância. A sua institucionalidade aumentou, mas isto não produziu progressos na luta contra a pobreza ou na criação de emprego" (Sica e Malamud, 2021). As possibilidades para a recuperação do bloco não são animadoras. Na revista The Economist, a pergunta é se o Mercosul ainda pode reverter décadas de recuos, pois:

no dia 26 de março, quando os atuais presidentes do grupo celebrarem o $30^{\circ}$ aniversário do Mercosul, não haverá muito para celebrar para além da sua mera sobrevivência. Uma primeira década de rápidos progressos na integração foi seguida de mais duas de recuos e protecionismo. O comércio interno no bloco atingiu o seu auge como parte do comércio total dos seus membros, com 25\% em 1997. Hoje esse número é de apenas 14\%. É verdade que o comércio global dos membros se expandiu grandemente, mas a maior parte desse crescimento verificou-se na exportação de mercadorias para a Ásia. (The Economist, 2021)

A bem da verdade, se levarmos em conta apenas os resultados econômicos, o Mercosul se revela um enorme fracasso:

Qualquer mente curiosa que queira saber quais são as economias mais fechadas do mundo só tem de consultar os Indicadores de Desenvolvimento Mundial do Banco Mundial. Aí verá que, em 2019, liderando o ranking, além do Sudão, da América de Trump e da Etiópia, estão o Brasil e a Argentina. Os dois países sul-americanos são as únicas duas economias que têm estado ininterruptamente nestas posições desde 1960, um fato que prova que o seu apoio 
moderado a políticas comerciais abertas transcende os seus ciclos políticos muito convulsivos. (Ruiz, 2021)

Para compreender as razões desses diagnósticos e fazer um balanço dessa grande aventura de integração regional por meio de um mercado comum do Sul, apresentamos aqui o dossiê sobre os trinta anos do Mercosul, coordenado por Karina L. Pasquariello Mariano e Roberto Goulart Menezes.

O dossiê se inicia com o artigo "O Brasil e o Mercosul: atores domésticos e oscilações da política externa nos últimos 30 anos", no qual Marcelo Passini, Haroldo Ramanzini Jr. e Tullo Vigevani analisam o Mercosul na política externa brasileira no período de 1991 a 2021 e argumentam que há uma trajetória de gradual perda de centralidade do bloco para a política externa brasileira e de redução nos níveis de intercâmbio comercial. Para estes autores, o declínio da prioridade do bloco para o Brasil, observado nos governos Temer e Bolsonaro, não pode ser considerado fato desenraizado de problemas que já se manifestavam nos governos anteriores, em verdade, desde 1995, ainda que com diferentes características.

No segundo texto, "O auge e crise do "novo Mercosul" do período post-hegemônico (2003-2016)”, José Briceño-Ruiz analisa o período pós-hegemônico do Mercosul, que vai de 2003 a 2015.

Em seguida, Detlef Nolte e Clarissa Correa Neto Ribeiro recuperam, no artigo "Mercosur and the EU: the false mirror", a longa história do acordo de livre comércio com a União Europeia e explicam por que as negociações entre a UE e o Mercosul avançaram tão lentamente e encontraram tantos obstáculos.

No quarto artigo, "El Mercosur como instrumento de inserción internacional argentina bajo un doble fuego: entre los poderes tradicionales y el ascenso de China”, Alejandro Simonoff afirma que o Mercosul tem sido um 
instrumento de sucesso para a estratégia de inserção da Argentina no mundo.

No texto seguinte, "Três décadas de Mercosul: institucionalidade, capacidade estatal e baixa intensidade da integração”, Karina L. Pasquariello Mariano e Roberto Goulart Menezes discutem como a tensão entre os defensores de um Mercosul mais aprofundado e de um Mercosul meramente comercial afetou a institucionalidade desse processo ao longo do tempo, assim como suscitou crises e relançamentos. Seu argumento é que a não construção de um consenso sobre qual o significado da cooperação no Mercosul e os seus objetivos, propiciou uma institucionalidade frágil e suscetível a retrocessos no processo de integração.

No sexto artigo, "Uruguay como Estado pequeño en el Mercosur (1991-2020): una lectura desde la autonomía regional", Camilo López Burian e María Cecilia Míguez trazem a experiência uruguaia sobre o Mercosul e destacam a importância da busca pela autonomia para a negociação com os outros membros do bloco.

Em seguida, Regiane Nitsch Bressan, Bruno Theodoro Luciano e Alexandre Fuccille mostram em "Para além do comércio: Mercosul, democracia e segurança regional” de que maneira o bloco contribuiu, desde sua formação, para a estabilidade democrática e a promoção da paz na região.

Por fim, o dossiê se encerra com o artigo "Paradigms, Institutional Changes and Policy Dismantling in the Mercosur Specialized Meeting on Family Farming”, no qual Cátia Grisa e Paulo Niederle analisam o desmantelamento da Reunião Especializada de Agricultura Familiar (Reaf), fórum do Mercosul responsável por propor políticas públicas para a agricultura familiar.

Este número de Lua Nova inclui ainda um último artigo avulso, "Análise comparada das estratégias organizativas dos lobbies no processo Constituinte de 1987-88", no qual Lucas Costa compara as distintas estratégias organizativas 
dos grupos de interesse nas áreas da Educação, Saúde e Trabalho durante o processo constituinte brasileiro de 198788. Embora o texto não faça parte do dossiê sobre os trinta anos do Mercosul, ele recupera o clima e o contexto de entusiasmo democrático no qual foi gestada a aproximação do Brasil com seus vizinhos do cone sul.

Todos os nove artigos foram enviados por seus autores ao sistema de submissão da SciELO e receberam uma avaliação positiva dos nossos pareceristas, aos quais muito agradecemos.

\section{Bibliografia}

JADOT, Yannick. 2021. Les régimes autoritaires ne comprennent que le rapport de force: il nous faut présenter un front uni. Le Monde, p. 31, 15 abr. 2021.

WESTIN, Ricardo. 2021. Há 30 anos, criação do Mercosul pôs fim às tensões históricas entre Brasil e Argentina. Arquivo S, 5 mar. 2021. SICA, Dante; MALAMUD, Andrés. 2021. El Mercosur se hunde en la irrelevância. La Nacion, 25 de marzo de 2021.

THE ECONOMIST. 2021. Can Mercosur reverse decades of backsliding? The South American trade group marks an unhappy 30th birthday. The Economist, 27 mar. 2021.

RUIZ, José Juan. 2021. Mercosur y el eterno retorno. El País, 4 abr. 2021.

\section{Bruno Konder Comparato}

aProfessor do Departamento de Ciências Sociais da Universidade Federal de São Paulo (Unifesp). Guarulhos, SP, Brasil.E-mail: bruno.comparato@unifesp.br

Orcid: 0000-0001-9356-0362

http://dx.doi.org/10.1590/0102-007011/112 